\title{
Water Relations and Gas Exchange in Alfalfa Leaves under Drought Conditions in Southern Tunisian Oases
}

\author{
Mabrouka Abid ${ }^{1 *}$, Mansour Haddad ${ }^{1}$, Abdenacer Ben Khaled ${ }^{1}$, Elhem Mansour ${ }^{1}$, \\ Khouloud Bachar ${ }^{1}$, Belgacem Lacheheb ${ }^{1}$, Ali Ferchichi ${ }^{2}$ \\ ${ }^{1}$ Institute of Arid Lands, Laboratory of Dry-Land Crops and Oases Crops, 4119 Medenine, Tunisia \\ ${ }^{2}$ National Institute of Agronomy, Tunis, Tunisia
}

Received: 30 October 2015

Accepted: 6 January 2016

\begin{abstract}
Water stress has become among the most limiting factors of productivity and plant development. To survive under these conditions, several plants have developed many strategies aimed at protecting plant functions. The aim of this study is to evaluate water stress effects on three alfalfa (Medicago sativa L.) populations (Chenini, Gannouch, and Tebelbou) cultivated in southern Tunisian oases. To investigate the effect of water stress on alfalfa, four treatment levels were applied: $25,50,75$, and 100\% (control) of field capacity with four replicates for each treatment. Drought application led to a high reduction $(\mathrm{p}<0.05)$ on net photosynthetic rate $\left(\mathrm{P}_{\mathrm{N}}\right)$, stomatal conductance $\left(g_{\mathrm{s}}\right)$, water use efficiency (WUE), relative water content (RWC), leaf area $\left(\mathrm{L}_{\mathrm{A}}\right)$, and chlorophyll a and $\mathrm{b}$ content while leading to an increase on water use efficiency of productivity $\left(\mathrm{WUE}_{\mathrm{p}}\right)$ and on intracellular $\mathrm{CO}_{2}$ concentration $\left(C_{\mathrm{i}}\right)$. Both stomatal and non-stomatal limitations govern photosynthesis variation in Medicago sativa plants. The Tebelbou population seems to be the most tolerant population as compared to the other two populations. This tolerance is due to its capacity to reduce the most $\left(\mathrm{L}_{\mathrm{A}}\right)$ in addition to maintaining the highest values for $\left(\mathrm{WUE}_{\mathrm{p}}\right)$, which are considered an adaptative mechanism to drought conditions.
\end{abstract}

Keywords: drought, limitation, Medicago sativa, photosynthesis, populations

\section{Introduction}

In arid and semi-arid lands, water deficit is becoming the main constraint of agricultural production [1]. Furthermore, with the increasing frequency of dry years, almost $50 \%$ of cultivated lands in the world are affected each year by drought [2]. Research on drought

*e-mail: abid.mabrouka@yahoo.fr response includes the study of many traits such as osmotic adjustment, water-saving strategies, and tissue tolerance to dehydration [3, 4], and it was concluded that this stress-induced disruption affects many physiological and metabolic features such as plant growth rate and yield [5$7]$, as well as changing net photosynthetic rate $[8,9]$.

The effect of water stress on photosynthesis has been intensively studied and a drastic reduction in photosynthesis parameters was observed $[10,11]$. Nevertheless, several lines of evidence indicate that this 
reduction has been attributed to both stomatal and nonstomatal limitations [12, 13]. Furthermore, stomatal closure is the first line of defense against desiccation, since it is much quicker than changes in roots growth, leaf area, chloroplast ultrastructure, and proteins [14]. In addition, it is often argued that the reduction in $C_{\mathrm{i}}$, as a result of stomatal closure, is the main cause of photosynthesis reduction [15]. Non-stomatal limitation of photosynthesis may be attributed to reduced ribulose-1, 5-bisphosphate (Rubp) regeneration [16] or to a reduced amount of functional Rubisco [17].

Drought affects other processes involved in the development of plants in arid regions, including leaf surface, biomass production, and water use efficiency (WUE). This parameter is a key factor that determines plant productivity and improves crop performance under drought conditions [18]. WUE was defined differently. In terms of agricultural production, this parameter can be calculated as the ratio of the produced dry matter and the quantity of the transpired water during a period of time and it is called water use efficiency of productivity (WUEp) [19]. For physiologists, it is calculated as the ratio of photosynthesis-transpiration $\left(\mathrm{P}_{\mathrm{N}} / \mathrm{E}\right)$. In previous studies, mild drought stress increased plant WUE; this increase is attained largely by stomatal closure, which will decrease transpiration, rather than by maintenance of photosynthetic activity [20].

Tunisia is among the places most highly threatened by water shortages. This problem is widespread, especially in the southern oases. These areas are subject to Saharan impact and are characterized by low and irregular rainfall (averaging between 100 and $200 \mathrm{~mm}$ per year), standing drought during the year and tight vegetation. Soils in these regions are shallow, with low organic matter content. Winds are relatively frequent, ranging from $40.7 \%$ in Medenine (southeastern Tunisia) to $66.4 \%$ in Kebili (in the southwest) with a speed upper to $4 \mathrm{~m} \mathrm{~s}^{-1}$ [21]. Southern Tunisian oases are known throughout history by their crucial role in the development of dry lands [22]. For this, it is necessary to preserve these regions from disappearance. The development of crop plants tolerant to various environmental stresses is a burgeoning field of stress biology and it is considered to be the most challenging. Additionally, in arid zones the use of plant species resistant to drought decreases the costs of both maintenance and watering, and it increases the plants' holding and survival successes [23]. Furthermore, understanding plants responses to drought and others stresses can play a major role in stabilizing crop performance and in the protection of natural vegetation.

Perennial alfalfa (Medicago sativa L.) is one of the most important legume forages all over the world and it is wildly planted in the southern Tunisian oases. This plant is particularly important as a high-quality forage crop and a source of value products [24]. Due to its capacity of symbiotic nitrogen fixation, lucerne is often used to improve soil fertility and particularly soil nitrogen content and has adapted to southern Tunisian farming regions.
It was observed that plants can adapt to changes over different timescales, and three adaptive strategies have been recognized as plant responses to drought: escape, avoidance, and tolerance [25]. In this context and as part of the approach aimed to investigate the physiological mechanisms underlying drought tolerance to water deficit stress in alfalfa, we investigated photosynthetic responses. The aim of the present study was to evaluate and compare the drought tolerance of three Medicago sativa populations that frequently existed in the southern oases of Tunisia and to identify an adaptation feature that enables alfalfa plants to survive drought. This study concerned the effects of water deficit on $\mathrm{P}_{\mathrm{N}}, \mathrm{E}, \mathrm{g}_{\mathrm{s}}, \mathrm{WUE}, \mathrm{WUE}_{\mathrm{p}}$, and $\mathrm{C}_{\mathrm{i}}$ in relation to $\mathrm{L}_{\mathrm{A}}$ and $\mathrm{RWC}$.

\section{Materials and Methods}

\section{Plant Material, Experimental Design, and Growth Conditions}

To investigate the effect of water stress on alfalfa, seeds of three populations of lucerne (Chenini, Gannouch, and Tebelbou) were collected from Gabes Coastal Oases (latitude $33^{\circ} 35^{\prime} \mathrm{N}$, longitude $10^{\circ} 48^{\prime} 3^{\prime}$ 'E, altitude $105 \mathrm{~m}$ ). Plants were planted in February 2009 in the experimental field of the Institute of Arid Lands in southern Tunisia. Plantings were done in pots (10L plastic pots), each pot contains a mixture of $2 / 3$ sand and $1 / 3$ oasis soil. All the samplings were well watered until complete leaf sprouting occurred and fully expanded leaves were visible. After a month of planting, the treatments were initiated.

The plants were then placed randomly in complete bloc design while maintaining five plants per pot. The plants were hydrated every two days with a quantity of water necessary to maintain the ideal moisture level in the substrate, corresponding to different percentages of field capacity. Four treatment levels were applied: 25, 50, 75, and $100 \%$ (control) of field capacity with four replicates for each treatment.

The study was undertaken for the spring period (corresponding to the early-flowering stage in alfalfa plants) in controlled conditions of a greenhouse with a thermoperiod of $26^{\circ} \mathrm{C}$ (day) and $18^{\circ} \mathrm{C}$ (night). Daily maximum relative humidity $(\mathrm{RH})$ ranged from 65 to $70 \%$. Average daily photo-synthetically active radiation (PAR) inside the greenhouse was $500 \mu \mathrm{mol} \mathrm{m} \mathrm{m}^{-2} \mathrm{~s}^{-1}$. All the sampling and measurements were made using fully expanded leaves of the third or fourth positions from the apex of the top branches.

\section{Measurement of Gas Exchange Parameters}

Gas exchange measurements were taken at the end of the experiment when plants were three months old. Net photosynthetic rate $\left(\mathrm{P}_{\mathrm{N}}\right)\left[\mu \mathrm{mol}\left(\mathrm{CO}_{2}\right) \mathrm{m}^{-2} \mathrm{~s}^{-1}\right]$, transpiration rate $(\mathrm{E})\left[\mathrm{mmol}\left(\mathrm{H}_{2} \mathrm{O}\right) \mathrm{m}^{-2} \mathrm{~s}^{-1}\right]$, stomatal conductance $\left(\mathrm{g}_{\mathrm{s}}\right)$ $\left[\mathrm{mol}\left(\mathrm{H}_{2} \mathrm{O}\right) \mathrm{m}^{-2} \mathrm{~s}^{-1}\right]$, and intracellular $\mathrm{CO}_{2}$ concentration

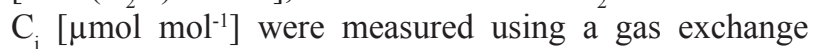


system device (LCi portable photosynthesis system, ADC Bio-Scientific, Hoddesdon, UK). All photosynthesis measurements were performed in situ on clear sunny mornings between 09:00 and 11:00.

\section{Water-use Efficiency}

WUE was calculated as $\mathrm{P}_{\mathrm{N}} / \mathrm{E}\left[\mu \mathrm{mol} \mathrm{CO} / \mathrm{mmol} \mathrm{H}_{2} \mathrm{O}\right]$. WUEp [mg (DM) $\left.\mathrm{g}^{-1}\left(\mathrm{H}_{2} \mathrm{O}\right)\right]$ was calculated as the ratio of dry matter produced to the water consumed in a period of time. For this experiment, WUEp was calculated at the end of the experiment, dry weight of collected parts (leaves, stems, and roots) was measured immediately. Total dry matter (DM) was taken after $48 \mathrm{~h}$ in $80^{\circ} \mathrm{C}$. Water quantity was measured as the volume of water consumed for the experiment. This consumed water was measured every two days as the difference between the quantity of water given in irrigation time and the quantity of water kept in the drain placed in the bottoms of the pots.

\section{Measurement of Chlorophyll $a$ and $b$}

To measure chlorophyll a (Chl a) and b (Chl b), 100 $\mathrm{mg}$ of fresh green leaves were cut at noon and crushed in mortar and pestle by adding $10 \mathrm{ml}$ of $80 \%$ acetone [26]. The mixture was filtered through a filter paper; the chlorophyll content was determined by a spectrophotometer (SECOMAN; ANTHELIE 5) at $663 \mathrm{~nm}$ (for Chl a) and $646 \mathrm{~nm}$ (for Chl b). The following formulas were used: $\mathrm{Chl} \mathrm{a}=12.7 \times(\mathrm{OD} 663)-2.67 \times(\mathrm{OD} 645)$ and $\mathrm{Chl}$ $\mathrm{b}=22.9 \times(\mathrm{OD} 645)-4.68 \times(\mathrm{OD} 663)$.

\section{Measurement of Leaf Area $\left(L_{A}\right)$}

To measure leaf surface $\left[\mathrm{cm}^{2}\right]$, fresh leaves were collected and placed on a scanner machine. The images obtained was treated with mesurim (7.0) (specialized software) to determine the total leaf surface.

\section{Relative Water Content (RWC)}

Leaf water status was determined by measuring the relative water content $(\%)$ calculated according to the method of [27]: RWC $\%=[(\mathrm{FM}-\mathrm{DM}) /(\mathrm{SM}-\mathrm{DM})]$ $\times 100$, where FM is leaf fresh mass, SM is the mass after rehydration obtained by storing leaf samples for $24 \mathrm{~h}$ in distilled water, and $\mathrm{DM}$ is oven dry mass $\left(105^{\circ} \mathrm{C}\right)$ of leaves.

\section{Statistical Analysis}

Data were subjected to general linear model (GLM) with water stress treatments and their interaction. When the effect was significant, differences between means were evaluated for significance using the LSD test $(\mathrm{P}=0.05)$. Statistical analysis was performed using SPSS software 18.0 for Windows statistical software package (SPSS, Chicago, IL, USA). Differences between populations were established by Duncan test. Data was represented as the mean value (four replications) with standard deviation of means $( \pm \mathrm{SD})$. Duncan test was used to evaluate the difference between treatment levels and between populations. Correlations were determined using Pearson correlation test. Relationships between photosynthesis assimilation and several parameters were established by linear regression lines test.

\section{Results}

Table 1 shows means, standard deviations of means, significance, and coefficients of variation of different parameters. Highest coefficients of variation were observed for $\mathrm{Chl}$ a and $\mathrm{Chl} \mathrm{b}$ content and WUE (respectively 57\%, $58 \%$, and $52 \%$ ), followed by $42 \%$ for $\mathrm{g}_{\mathrm{s}}, 35 \%$ for $\mathrm{C}_{\mathrm{i}}$, and $37 \%$ for $\mathrm{P}_{\mathrm{N}}$; low coefficients were observed for $\mathrm{E}$ and RWC $29 \%$.

Drought application led to a highly significant reduction on $\mathrm{P}_{\mathrm{N}}(\mathrm{p}<0.05)$ as shown in Table 1 . Values were between 4.36 and $7.13 \mu \mathrm{mol}\left(\mathrm{CO}_{2}\right) \mathrm{m}^{-2} \mathrm{~s}^{-1}$ for plants subjected to $25 \%$ of field capacity treatment, while for plants under control condition values ranged between 13.91 and $17.58 \mu \mathrm{mol}\left(\mathrm{CO}_{2}\right) \mathrm{m}^{-2} \mathrm{~s}^{-1}$. Although for stressed and control plants Gannouch showed highest $\mathrm{P}_{\mathrm{N}}$, Tebelbou showed lowest values (Table 2).

$\mathrm{g}_{\mathrm{s}}$ was reduced significantly and progressively $(\mathrm{p}<0.05)$ (Table 1). 25 and $50 \%$ of field capacity treatments affected the most $\mathrm{g}_{\mathrm{s}}$. Tebelbou showed the most reduced values as compared to the two others populations (Table 2).

Table 1 showed that water stress has a significant effect on E. Between populations, there is a very big difference $(p<0.05)$, with the highest reduction of E occurring for Gannouch, followed by Tebelbou and Chenini populations (Table 2).

Water stress induced progressive reduction on WUE $(p<0.05)$. Means passed from a maximum average of 4.45 for plants exposed to control conditions to an average of 1.73 for plants exposed to severe stress. Highest values were recorded for Gannouch for control and stressed plants, whereas, Tebelbou showed the most reduced value for the same treatments.

Chlorophyll content decreased significantly with increased stress levels (Table 1), while Tebelbou showed the most reduced values (Table 2).

Water stress led to a significant increase of $\mathrm{C}_{\mathrm{i}}$. The highest values were registered under severe stress levels (25 and $50 \%$ of field capacity; Table 1). Gannouch exhibited the highest values, especially under severe stress conditions, while the lowest values were recorded for Tebelbou, subject to the same conditions (Table 2).

The change in RWC was highly significant $(\mathrm{p}<0.05)$ depending on the applied stress levels. For the non-stressed plants, Chenini presented the maximum value of RWC at $90 \%$. Furthermore, Tebelbou presented the highest value as $57 \%$ for moderate stress ( $75 \%$ of field capacity) and $45 \%$ for treatment ( $50 \%$ of field capacity).

The variation of $\mathrm{WUE}_{\mathrm{p}}$ shown in Fig. 1 indicates that this parameter increased progressively with the increasing 
Table 1. Results of one-way ANOVA at 0.05 on the effects of SL, POP, and their interactions with Chl, $C_{\mathrm{i}}, \mathrm{E}, g_{\mathrm{s}}, P_{\mathrm{N}}, \mathrm{RWC}$, and WUE (see Abbreviations for explanations). Presented data are means and standard errors $( \pm \mathrm{SD})$ of four replicate plants. Coefficients of variation (CV) were calculated as standard deviation-means ratio.

Significance is designed: *: significant at $p<0.05$; **: highly significant at $p<0.01$, and NS $=$ not significant. a) Chenini population,

b) Gannouch population, c) Tebelbou population.

Values followed by the same letter are not significantly different at 5\%.

a)

\begin{tabular}{|c|c|c|c|c|c|c|c|c|c|}
\hline \multirow{2}{*}{ Parameters } & \multicolumn{4}{|c|}{ Stress Levels ( $\%$ of field capacity) } & \multicolumn{5}{|c|}{ Significance } \\
\hline & $25 \%$ & $50 \%$ & $75 \%$ & $100 \%$ & & SL & POP & $\mathrm{SL} * \mathrm{POP}$ & $\mathrm{CV}(\%)$ \\
\hline$P_{\mathrm{N}}\left[\mu \mathrm{mol}\left(\mathrm{CO}_{2}\right) \mathrm{m}^{-2} \mathrm{~s}^{-1}\right]$ & $6.28 \pm 1.09^{\mathrm{a}}$ & $10.88 \pm 1.05^{\mathrm{b}}$ & $14.8 \pm 1.05^{\mathrm{c}}$ & $15.34 \pm 1.05^{\mathrm{c}}$ & $P_{\mathrm{N}}$ & $*$ & $*$ & NS & 37 \\
\hline$E\left[\mathrm{mmol}\left(\mathrm{CO}_{2}\right) \mathrm{m}^{-2} \mathrm{~s}^{-1}\right]$ & $4.31 \pm 0.75^{\mathrm{a}}$ & $6.63 \pm 0.55^{\mathrm{a}}$ & $5.73 \pm 0.55^{\mathrm{a}}$ & $6.23 \pm 0.65^{\mathrm{a}}$ & $E$ & $* *$ & $*$ & $*$ & 29 \\
\hline$g_{\mathrm{s}}\left[\mathrm{mol}\left(\mathrm{CO}_{2}\right) \mathrm{m}^{-2} \mathrm{~s}^{-1}\right]$ & $0.08 \pm 0.05^{\mathrm{a}}$ & $0.13 \pm 0.01^{\mathbf{b}}$ & $0.16 \pm 0.01^{\mathrm{c}}$ & $0.18 \pm 0.15^{\mathrm{d}}$ & $g_{\mathrm{s}}$ & $*$ & $*$ & NS & 42 \\
\hline $\begin{array}{l}\text { WUE }\left[\mu \mathrm{mol}\left(\mathrm{CO}_{2}\right) \mathrm{mmol}\right. \\
\left.\left(\mathrm{H}_{2} \mathrm{O}\right)^{-1}\right]\end{array}$ & $1.73 \pm 0.05^{\mathrm{a}}$ & $2.72 \pm 0.05^{\mathrm{a}}$ & $2.8 \pm 0.05^{\mathbf{b}}$ & $2.33 \pm 0.05^{\mathrm{b}}$ & WUE & $*$ & $*$ & $*$ & 52 \\
\hline Chl $a[\%]$ & $4.68 \pm 0.85^{\mathrm{a}}$ & $8.63 \pm 0.85^{\mathrm{b}}$ & $10.45 \pm 0.75^{\mathrm{c}}$ & $16.68 \pm 0.86^{\mathrm{d}}$ & Chl $a$ & $*$ & * & NS & 58 \\
\hline $\mathrm{Chl} b[\%]$ & $2.23 \pm 0.45^{\mathrm{a}}$ & $3.11 \pm 0.52^{\mathrm{b}}$ & $4.83 \pm 0.42^{\mathrm{c}}$ & $7.39 \pm 0.45^{\mathrm{d}}$ & $\mathrm{Chl} b$ & $* *$ & NS & NS & 57 \\
\hline RWC [\%] & $37.67 \pm 1.59^{\mathrm{a}}$ & $44.62 \pm 2.09^{\mathrm{b}}$ & $57.54 \pm 0.09^{\mathrm{c}}$ & $87 \pm 1.19^{d}$ & RWC & $*$ & $* *$ & NS & 29 \\
\hline$C_{\mathrm{i}}\left[\mu \mathrm{molCO}_{2} \mathrm{~m}^{-2} \mathrm{~s}^{-1}\right]$ & $247 \pm 0.59^{\mathrm{a}}$ & $198 \pm 0.79^{b}$ & $149 \pm 0.59^{c}$ & $126 \pm 1.39^{\mathrm{d}}$ & $C_{\mathrm{i}}$ & $*$ & $*$ & NS & 35 \\
\hline
\end{tabular}

b)

\begin{tabular}{|c|c|c|c|c|c|c|c|c|c|}
\hline \multirow{2}{*}{ Parameters } & \multicolumn{4}{|c|}{ Stress Levels ( $\%$ of field capacity) } & \multicolumn{5}{|c|}{ Significance } \\
\hline & $25 \%$ & $50 \%$ & $75 \%$ & $100 \%$ & & SL & POP & SL*POP & $\mathrm{CV}(\%)$ \\
\hline$P_{\mathrm{N}}\left[\mu \mathrm{mol}\left(\mathrm{CO}_{2}\right) \mathrm{m}^{-2} \mathrm{~s}^{-1}\right]$ & $7.13 \pm 1.05^{\mathrm{a}}$ & $12.34 \pm 1.15^{\mathrm{b}}$ & $17.02 \pm 1.16^{\mathrm{c}}$ & $17.58 \pm 1.05^{\mathrm{c}}$ & $P_{\mathrm{N}}$ & $*$ & $*$ & NS & 37 \\
\hline$E\left[\mathrm{mmol}\left(\mathrm{CO}_{2}\right) \mathrm{m}^{-2} \mathrm{~s}^{-1}\right]$ & $2.77 \pm 0.62^{\mathrm{a}}$ & $4.03 \pm 0.75^{\mathrm{a}}$ & $4.29 \pm 0.55^{\mathrm{a}}$ & $3.97 \pm 0.65^{\mathrm{a}}$ & $E$ & $* *$ & $*$ & $*$ & 29 \\
\hline$g_{\mathrm{s}}\left[\mathrm{mol}\left(\mathrm{CO}_{2}\right) \mathrm{m}^{-2} \mathrm{~s}^{-1}\right]$ & $0.06 \pm 0.05^{\mathrm{a}}$ & $0.10 \pm 0.05^{\mathrm{b}}$ & $0.12 \pm 0.05^{\mathrm{c}}$ & $0.14 \pm 0.05^{\mathrm{d}}$ & $g_{\mathrm{s}}$ & $*$ & $*$ & NS & 42 \\
\hline $\begin{array}{c}\text { WUE }\left[\mu \mathrm{mol}\left(\mathrm{CO}_{2}\right) \mathrm{mmol}\right. \\
\left.\left(\mathrm{H}_{2} \mathrm{O}\right)^{-1}\right]\end{array}$ & $2.63 \pm 0.95^{\mathrm{a}}$ & $3.1 \pm 0.75^{\mathrm{a}}$ & $3.97 \pm 0.75^{\mathrm{b}}$ & $4.45 \pm 0.45^{\mathrm{b}}$ & WUE & $*$ & $*$ & $*$ & 52 \\
\hline Chl $a[\%]$ & $2.35 \pm 0.15^{\mathrm{a}}$ & $7.26 \pm 0.15^{\mathrm{b}}$ & $10.78 \pm 0.75^{\mathrm{c}}$ & $16.36 \pm 0.95^{\mathrm{d}}$ & Chl $a$ & $*$ & $*$ & NS & 58 \\
\hline Chl $b[\%]$ & $1.19 \pm 0.35^{\mathrm{a}}$ & $3.01 \pm 0.45^{\mathrm{b}}$ & $5.33 \pm 0.35^{\mathfrak{c}}$ & $8.05 \pm 0.35^{\mathrm{d}}$ & Chl $b$ & $* *$ & NS & NS & 57 \\
\hline RWC $[\%]$ & $42.7 \pm 0.05^{\mathrm{a}}$ & $52.64 \pm 1.05^{\mathrm{b}}$ & $60.8 \pm 1.29^{c}$ & $78.3 \pm 0.09^{\mathrm{d}}$ & RWC & $*$ & $* *$ & NS & 29 \\
\hline$C_{\mathrm{i}}\left[\mu \mathrm{molCO}_{2} \mathrm{~m}^{-2} \mathrm{~s}^{-1}\right]$ & $257 \pm 1.59^{\mathrm{a}}$ & $210 \pm 2.29^{b}$ & $15 \pm 1.01^{\mathrm{c}}$ & $142 \pm 1.05^{\mathrm{d}}$ & $C_{\mathrm{i}}$ & $*$ & $*$ & NS & 35 \\
\hline
\end{tabular}

c)

\begin{tabular}{|c|c|c|c|c|c|c|c|c|c|}
\hline \multirow{2}{*}{ Parameters } & \multicolumn{4}{|c|}{ Stress Levels ( $\%$ of field capacity) } & \multicolumn{5}{|c|}{ Significance } \\
\hline & $25 \%$ & $50 \%$ & $75 \%$ & $100 \%$ & & SL & POP & SL*POP & $\mathrm{CV}(\%)$ \\
\hline$P_{\mathrm{N}}\left[\mu \mathrm{mol}\left(\mathrm{CO}_{2}\right) \mathrm{m}^{-2} \mathrm{~s}^{-1}\right]$ & $4.36 \pm 1.06^{\mathrm{a}}$ & $9.29 \pm 1.15^{\mathrm{b}}$ & $11.1 \pm 1.05^{\mathrm{c}}$ & $13.91 \pm 0.95^{\mathrm{c}}$ & $P_{\mathrm{N}}$ & $*$ & $*$ & NS & 37 \\
\hline$E\left[\mathrm{mmol}\left(\mathrm{CO}_{2}\right) \mathrm{m}^{-2} \mathrm{~s}^{-1}\right]$ & $3.61 \pm 0.65^{\mathrm{a}}$ & $4.10 \pm 0.65^{\mathrm{a}}$ & $5.28 \pm 0.65^{\mathrm{a}}$ & $6.56 \pm 0.65^{\mathrm{a}}$ & $E$ & $* *$ & $*$ & $*$ & 29 \\
\hline$g_{\mathrm{s}}\left[\mathrm{mol}\left(\mathrm{CO}_{2}\right) \mathrm{m}^{-2} \mathrm{~s}^{-1}\right]$ & $0.05 \pm 0.85^{\mathrm{a}}$ & $0.07 \pm 0.65^{b}$ & $0.1 \pm 0.65^{\mathrm{c}}$ & $0.12 \pm 0.85^{\mathrm{d}}$ & $g_{\mathrm{s}}$ & $*$ & $*$ & NS & 42 \\
\hline $\begin{array}{c}\text { WUE }\left[\mu \mathrm{mol}\left(\mathrm{CO}_{2}\right) \mathrm{mmol}\right. \\
\left.\left(\mathrm{H}_{2} \mathrm{O}\right)^{-1}\right]\end{array}$ & $1.01 \pm 0.05^{\mathrm{a}}$ & $1.42 \pm 0.05^{\mathrm{a}}$ & $1.95 \pm 0.05^{\mathrm{b}}$ & $2.31 \pm 0.05^{\mathrm{b}}$ & WUE & $*$ & $*$ & $*$ & 52 \\
\hline Chl $a[\%]$ & $1.86 \pm 0.95^{\mathrm{a}}$ & $4.38 \pm 0.35^{\mathrm{b}}$ & $7.67 \pm 0.39^{\mathrm{c}}$ & $15.02 \pm 0.75^{\mathrm{d}}$ & Chl $a$ & $*$ & $*$ & NS & 58 \\
\hline $\mathrm{Chl} b[\%]$ & $1.26 \pm 0.55^{\mathrm{a}}$ & $2.69 \pm 1.25^{\mathrm{b}}$ & $4.37 \pm 1.05^{\mathrm{c}}$ & $7.01 \pm 0.75^{\mathrm{d}}$ & $\mathrm{Chl} b$ & $* *$ & NS & NS & 57 \\
\hline RWC [\%] & $36.33 \pm 1.04^{\mathrm{a}}$ & $45 \pm 1.75^{\mathrm{b}}$ & $60.54 \pm 0.09^{c}$ & $75.61 \pm 1.07^{\mathrm{d}}$ & RWC & $*$ & $* *$ & NS & 29 \\
\hline$C_{\mathrm{i}}\left[\mu \mathrm{molCO}_{2} \mathrm{~m}^{-2} \mathrm{~s}^{-1}\right]$ & $235 \pm 1.69^{\mathrm{a}}$ & $189 \pm 1.34^{\mathrm{b}}$ & $168 \pm 1.05^{\mathrm{c}}$ & $67 \pm 1.01^{\mathrm{d}}$ & $C_{\mathrm{i}}$ & $*$ & $*$ & NS & 35 \\
\hline
\end{tabular}




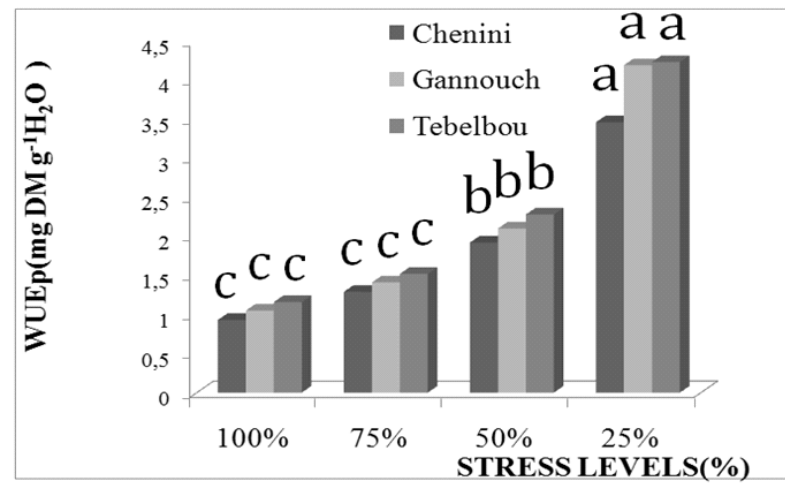

Fig. 1. The change of water use efficiency of productivity (WUE $)$ in alfalfa populations - Chenini (CH), Gannouch (GAN), Tebelbou (TEB) - subjected to four levels of water stress $(25 \%, 50 \%$, $75 \%$, and $100 \%$ of field capacity). Values followed by the same letter are not significantly different at $5 \%$.

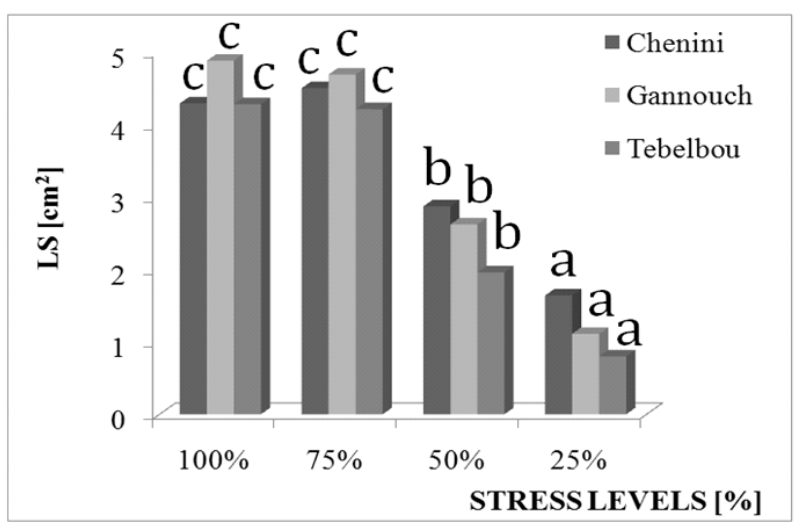

Fig. 2. The change of leaf area $\left(\mathrm{L}_{\mathrm{A}}\right)$ in alfalfa populations - Chenini (CHEN), Gannouch (GAN), Tebelbou (TEB) subjected to four levels of water stress $(25 \%, 50 \%, 75 \%$, and $100 \%$ of field capacity). Values followed by the same letter are not significantly different at $5 \%$.

stress level $(\mathrm{p}<0.05)$. Tebelbou exhibited the highest values for all the applied treatments, followed by Gannouch and Chenini populations (Table2).

Applying water stress induced a significant reduction on $\mathrm{L}_{\mathrm{A}}(\mathrm{p}<0.05)$. This reduction was especially accentuated for plants subjected to severe stress levels (Fig. 2). Tebelbou exhibited the lowest values (Table 2).
Pearson correlation analysis and regression lines shown in Tables 3 and 4 indicated that, overall, the coefficient of correlations (R) between different studied parameters are high and significant $(p<0.01)$, with values ranging between 0.161 and 0.900 . Regression slopes indicated that $\mathrm{C}_{\mathrm{i}}, \mathrm{WUE}, \mathrm{L}_{\mathrm{A}}, \mathrm{RWC}$, and $\mathrm{g}_{\mathrm{S}}$ explained, respectively, $81 \%, 77 \%, 66 \%, 58 \%$, and $44 \%$ of the variation of $\mathrm{P}_{\mathrm{N}}$ at $1 \%$.

\section{Discussion}

In response to drought, gas exchange parameters such as $P_{\mathrm{N}}, E, g_{\mathrm{s}}$, and WUE were reduced. It is observed that this reduction is greater for $g_{\mathrm{s}}$ and $\mathrm{P}_{\mathrm{N}}$. Furthermore, both variables showed a significant relationship $(p<0.01$, $R^{2}=0.633$ ). This reinforces the hypothesis that the reduction of photosynthesis assimilation is almost associated with a stomatal conductance reduction under drought conditions. The same result was observed in alfalfa plants cultivated in China [28] and in Tunisia when their stress tolerance appears to be associated by their stomatal control of gas exchange [29]. However, photosynthesis limitation has often been attributed to a combination of stomatal and non-stomatal limitations [30].

In this study we observed that a reduction on $\mathrm{P}_{\mathrm{N}}$ is negatively correlated with $\mathrm{C}_{\mathrm{i}}\left(p<0.001, R^{2}=-0.900\right)$. These findings are in accord with the same studies showing that photosynthesis reduction is accompanied by a slight increase in $\mathrm{C}_{\mathrm{i}}$ in alfalfa [31]. Overall, this increase is explained by indirect evidence of reduced mesophyll photosynthetic capacity, as carbon uptake becomes more limiting under water scarcity and respiration increases proportionally, leading to an increase in leaf intracellular $\mathrm{CO}_{2}$, altering plant carbon balance [32]. The correlation coefficient of $\mathrm{P}_{\mathrm{N}}$ with $\mathrm{L}_{\mathrm{A}}$ was highly significant $(p<0.001$, $R^{2}=0.815$ ). Based on this data - and although it is generally accepted that stomatal closure is the main factor limiting photosynthetic activity under drought conditions - in this study non-stomatal limitations seem to be the main factor influencing photosynthesis assimilation. This is in agreement with [33], which suggests the major implication of non-stomatal factors in the decline of photosynthesis especially under severe drought conditions.

The reduction of $g_{s}$ is a major process of water economy by reducing transpiration. The same results were found in this study; however an insignificant correlation between

Table 2. Results of Duncan-test analysis at 0.05 on the effects of drought on the three studied populations (G: gannouch population, $\mathrm{CH}$ : chenini population, T: Tebelbou population) for different parameters: net photosynthesis rate $\left(P_{\mathrm{N}}\right)$, stomatal conductance $\left(g_{\mathrm{s}}\right)$, transpiration $(E)$, water use efficiency (WUE), content of chlorophyll a and b, relative water content (RWC), intracellular $\mathrm{CO}_{2}$ concentration $\left(C_{\mathrm{i}}\right)$, leaf $\operatorname{area}\left(\mathrm{L}_{\mathrm{A}}\right)$, and water use efficiency of productivity (WUE $)$. Values followed by the same letter are not significantly different at $5 \%$.

\begin{tabular}{|c|c|c|c|c|c|c|c|c|c|c|}
\hline & $P_{\mathrm{N}}$ & $E$ & $g_{\mathrm{s}}$ & $P_{\mathrm{N}} / E$ & $\mathrm{Chl} a$ & $\mathrm{Chl} b$ & $C_{\mathrm{i}}$ & $\mathrm{L}_{\mathrm{A}}$ & WUE $_{\mathrm{p}}$ & RWC \\
\hline $\mathrm{G}$ & $\mathrm{a}$ & $\mathrm{c}$ & $\mathrm{b}$ & $\mathrm{a}$ & $\mathrm{a}$ & $\mathrm{a}$ & $\mathrm{b}$ & $\mathrm{a}$ & $\mathrm{c}$ & $\mathrm{a}$ \\
\hline $\mathrm{CH}$ & $\mathrm{b}$ & $\mathrm{b}$ & $\mathrm{b}$ & $\mathrm{a}$ & $\mathrm{a}$ & $\mathrm{ab}$ & $\mathrm{a}$ & $\mathrm{a}$ & $\mathrm{b}$ & $\mathrm{ab}$ \\
\hline $\mathrm{T}$ & $\mathrm{c}$ & $\mathrm{a}$ & $\mathrm{a}$ & $\mathrm{b}$ & $\mathrm{b}$ & $\mathrm{a}$ & $\mathrm{c}$ & $\mathrm{a}$ & $\mathrm{a}$ & $\mathrm{a}$ \\
\hline
\end{tabular}


Table 3. Pearson correlation between photosynthesis assimilation $\left(P_{\mathrm{N}}\right)$, stomatal conductance $\left(g_{\mathrm{s}}\right)$, transpiration $(E)$, relative water content $(\mathrm{RWC})$, chlorophyll (a and b) content, leaf area $\left(\mathrm{L}_{\mathrm{A}}\right)$, water use efficiency of productivity (WUE $)_{\mathrm{p}}$, and intercellular $\mathrm{CO}_{2}$ concentration $\left(C_{\mathrm{i}}\right)$ for Medicago sativa plants subjected to water stress.

In bold, correlations significant at 5\%.

\begin{tabular}{|c|c|c|c|c|c|c|c|c|c|}
\hline & $\mathrm{L}_{\mathrm{A}}$ & $P_{\mathrm{N}}$ & $\mathrm{Chl} a$ & $\mathrm{Chl} b$ & $g_{\mathrm{s}}$ & $E$ & $\mathrm{RWC}$ & $C_{\mathrm{i}}$ & $\mathrm{WUE}_{\mathrm{p}}$ \\
\hline $\mathrm{L}_{\mathrm{A}}$ & - & $\mathbf{0 . 8 1 5}$ & $\mathbf{0 . 8 1 6}$ & $\mathbf{0 . 8 6 5}$ & -0.319 & $\mathbf{0 . 7 4 0}$ & $\mathbf{0 . 8 5 3}$ & $\mathbf{- 0 . 8 5 2}$ & $-\mathbf{0 . 9 4 5}$ \\
\hline$P_{\mathrm{N}}$ & & - & $\mathbf{0 . 8 2 8}$ & $\mathbf{0 . 7 4 0}$ & $\mathbf{0 . 6 3 3}$ & -0.161 & $\mathbf{0 . 7 1 2}$ & $\mathbf{- 0 . 9 0 0}$ & $-\mathbf{0 . 8 8 0}$ \\
\hline $\mathrm{Chl} a$ & & & - & $\mathbf{0 . 8 9 0}$ & $\mathbf{0 . 7 1 2}$ & -0.049 & $\mathbf{0 . 8 6 6}$ & $-\mathbf{0 . 9 1 2}$ & $-\mathbf{0 . 8 6 4}$ \\
\hline $\mathrm{Chl} b$ & & & & - & $\mathbf{0 . 6 3 9}$ & 0.061 & $\mathbf{0 . 8 4 8}$ & $\mathbf{- 0 . 9 6 0}$ & $-\mathbf{0 . 8 7 8}$ \\
\hline$g_{\mathrm{s}}$ & & & & & - & 0.134 & $\mathbf{0 . 6 8 4}$ & $\mathbf{- 0 . 7 0 6}$ & $-\mathbf{0 . 8 5 2}$ \\
\hline$E$ & & & & & & - & 0.010 & 0.162 & -0.141 \\
\hline RWC & & & & & & & - & $-\mathbf{0 . 8 5 9}$ & $-\mathbf{0 . 8 2 5}$ \\
\hline$C_{\mathrm{i}}$ & & & & & & & & - & $\mathbf{0 . 8 6 6}$ \\
\hline $\mathrm{WUE}_{\mathrm{p}}$ & & & & & & & & - \\
\hline
\end{tabular}

$P_{\mathrm{N}}$ and $E$ was detected. $\left(p<0.001, R^{2}=-0.161\right)$. These results corroborate with similar other studies indicating that in most cases there was no direct correlation between these two parameters. [34].

A reduction of WUEi is observed, especially for stressed plants. This result is in agreement with others showing that under severe stress conditions instantaneous water use efficiency (WUE $_{\mathrm{j}}$ ) decreases sharply in Medicago sativa and Medicago falcata plants [28].

Contrary to WUEi, WUE increased in response to drought for alfalfa plants. This change is considered a key factor determining plant productivity under limited water supply [35], and it is mentioned as an adaptive response and a strategy to improve crop performance under limited water conditions [14]. In accordance with our results, many studies have found that WUE increased with increasing water stress in alfalfa plants [36]. This change keeps being controversial, because improving WUE may conflict with the high growth rate for many species [37]. Improving WUE in water-stressed plants is reinforced in this study by the Correlations coefficients

Table 4. Linear regressions between photosynthesis assimilation $\left(P_{\mathrm{N}}\right)$, stomatal conductance $\left(g_{\mathrm{s}}\right)$, transpiration $(E)$, relative water content (RWC), chlorophyll (a and b) content, leaf area $\left(\mathrm{L}_{\mathrm{A}}\right)$, water use efficiency of productivity (WUE $\mathrm{p}_{\mathrm{p}}$ ), and intercellular $\mathrm{CO}_{2}$ concentration $\left(C_{\mathrm{i}}\right)$ for Medicago sativa plants subjected to water stress.

\begin{tabular}{|c|c|c|c|}
\hline Parameters & $R^{2}$ & Regressions equations & Significance \\
\hline $\mathrm{P}_{\mathrm{N}}-g_{\mathrm{s}}$ & 0.44 & $\mathrm{y}=74.002 * \mathrm{~g}_{\mathrm{s}}+8.276$ & $p<0.01$ \\
\hline$P_{\mathrm{N}}-E$ & 0.05 & $\mathrm{y}=-0.979 * \mathrm{E}+0.088$ & $p>0.01$ \\
\hline$P_{\mathrm{N}}-\mathrm{RWC}$ & 0.58 & $\mathrm{y}=0.197 * \mathrm{RWC}+0.44$ & $p<0.01$ \\
\hline$P_{\mathrm{N}}-\mathrm{L}_{\mathrm{A}}$ & 0.66 & $\mathrm{y}=0.819 * \mathrm{~L}_{\mathrm{A}}+0.572$ & $p<0.01$ \\
\hline$P_{\mathrm{N}}-\mathrm{WUE}$ & 0.77 & $\mathrm{y}=-1.940 * \mathrm{WUE}_{\mathrm{p}}+0.743$ & $p<0.01$ \\
\hline$P_{\mathrm{N}}-\mathrm{RWC}$ & 0.81 & $\mathrm{y}=0.008 * \mathrm{C}_{\mathrm{i}}+0.013$ & $p<0.01$ \\
\hline
\end{tabular}

$\left(R^{2}\right)$ between $\mathrm{WUE}_{\mathrm{p}}$ and $\mathrm{P}_{\mathrm{N}}$ and $\mathrm{g}_{\mathrm{s}}$, respectively -0.880 and -0.852 .

Drought has a significant effect on chlorophyll content, especially chlorophyll a. This finding is consistent with others in Paulownia imperialis [38] and in others [39, 40]. This decrease has been explained by some authors as a photoprotection mechanism through reducing light absorbance [41]. Some studies have suggested that photosynthesis may also be controlled by the chloroplast's capacity to fix $\mathrm{CO}_{2}$ in Tunisian alfalfa species [29]. This seems to be in agreement with our study showing a high and significant correlation coefficient between $\mathrm{Chl}$ a and $\mathrm{b}$ content and $P_{\mathrm{N}}\left(p<0.001 ; R^{2}=0.828 ; R^{2}=0.740\right.$, respectively).

Drought decreased RWC in this study. The same result was observed in alfalfa plants [31] and in several legume cultivars such as Phaselus vulgaris [42] and Lupinus albus [43]. RWC is related and positively correlated with other parameters such as $\mathrm{P}_{\mathrm{N}}, \mathrm{g}_{\mathrm{s}}$, and chlorophyll content $\left(R^{2}=0.712,0.684,0.866\right.$, and 0.848 , respectively). These results agree with the results for Aeluropus lagopoides [44].

Drought application also leads to decreasing $\mathrm{L}_{\mathrm{A}}$, which is more pronounced under severe stress conditions. The same results are shown by [45] and [46] in alfalfa plants. This response was qualified as an adaptation that can diminish consumption of water at the foliar level and increase absorption of water at the root level [37], which may suggest higher drought resistance. The highest correlation coefficients between $\mathrm{L}_{\mathrm{A}}$ and $E(0.740)$ and WUE $_{p}(0.945)$ reinforce the idea that the smaller surface area contributes to the limitation of water loss by lowering transpiration.

Regressions equations (Table 3) showed that linear slopes were variables indicating that photosynthesis assimilation is related to $\mathrm{C}_{\mathrm{i}}, \mathrm{WUE}_{\mathrm{p}}, \mathrm{L}_{\mathrm{A}}, \mathrm{RWC}$, and $\mathrm{g}_{\mathrm{s}}$. Consequently, we can suggest that both stomatal and nonstomatal limitations govern photosynthesis variation in alfalfa plants. 


\section{Conclusion}

The present study found the Tebelbou population to be the most affected by stress conditions as it exhibited the lowest values for $\mathrm{P}_{\mathrm{N}}, \mathrm{Chl}$ content, WUE, $\mathrm{C}_{\mathrm{i}}$, and $\mathrm{L}_{\mathrm{A}}$. The Gannouch population exhibit the lowest values for $g_{\mathrm{s}}$ and E. Based on this data, the Tebelbou population seems to be the most tolerant. This tolerance is due to its capacity to reduce leaf surface in addition of maintaining the highest values for $\mathrm{WUE}_{\mathrm{p}}$ which are considered an adaptative mechanism for drought conditions.

The variability of drought tolerance between the studied populations may be related to their different growing origins, which has been proven in many studies, indicating that the tolerances of different origins to drought stress are different. But there are a few comparative studies of alfalfa cultivars differing in their drought tolerance. Thus the evaluation of genotypic variability to water deficit is necessary for proposing new breeding programs. Besides, conducting similar studies on different species is an important way to identify the most resistant species to drought.

Photosynthesis is a very important life process for plants because it is a source of energy and nutrients, so it very important to study the variation of this process in relation to different stresses. However, our investigation is a small step in the study of photosynthesis and can be followed by a more comprehensive study.

\section{Abbreviations}

Chl - chlorophyll, $\mathrm{C}_{\mathrm{i}}$ - intercellular $\mathrm{CO}_{2}$ concentration, $\mathrm{E}$ - transpiration, $\mathrm{g}_{\mathrm{s}}-$ stomatal conductance, $\mathrm{L}_{\mathrm{A}}-$ Leaf area, $\mathrm{P}_{\mathrm{N}}$ - net photosynthetic rate, POP - populations, RWC -relative water content, SL - stress levels, WUE - water use efficiency, $\mathrm{WUE}_{\mathrm{p}}$ - water use efficiency of productivity, Rubp - ribulose-1, 5-bisphosphate

\section{References}

1. SIAM A.M.J., RADOGLOU K.M., BASILIOS N., SMIRIS P. Differences in ecophysiological responses to summer drought between seedlings of three deciduous oak species. Forest Ecol Man. 258, 35, 2009.

2. WANG W., SCALI M., VIGNANI R., SPADAFORA A, SENSI E, MAZZUCA S., CRESTI M. Protein extraction for two-dimensional electrophoresis from olive leaf, a plant tissue containing high levels of interfering compounds. Electrophoresis. 24, 2369, 2003.

3. RICHARDS R.A. Physiological traits used in the breeding of new cultivars for water-scarce environments. Agr Water Mng. 80, 197, 2006.

4. COLLINS NC., TARDIEU F., TUBEROSA R. Quantitative trait loci and crop performance under stress: where do we stand?. Plant Physiol. 147, 469, 2008.

5. SHAO HB., LIANG ZS., SHAO MA., SUN SM., HU ZM. Investigation on dynamic changes of photosynthetic traits of 10 wheat (Triticum aestivum L.) genotypes during two vegetative-growth stages at water deficitsB. Biointerfaces.

\section{3, 221, 2005a}

6. NI FT., CHU LY., SHAO HB., LIU ZH. Gene expression and regulation of higher plants under soil water stress .Curr Genomics.10, 269, 2009.

7. CRAMER GR., URANO K., DELROT S., PEZZOTTI M., SHINOZAKI K. Effects of abiotic stress on plants: a systems biology perspective . BMC Plant Biol.11, 163, 2011.

8. ARAUS JL., SLAFER GA., ROYO C., SERRET MD. Breeding for yield potential and stress adaptation in cereals. Crit Rev Plant Sci. 27, 377, 2008.

9. AKHKHA A., BOUTRAA T., ALHEJELY A. The rates of photosynthesis, chlorophyll content, dark respiration, proline and abscicic acid (ABA) in wheat (Triticum durum) under water deficit conditions. Int J Agric Biol. 13, 215, 2011.

10. SAIBO N.J.M., LOURENÇO T., OLIVEIRA M.M. Transcription factors and regulation of photosynthetic and related metabolism under environmental stresses. Ann. Bot, 103,609, 2009.

11. RAHNAMA A., POUSTINI K., TAVAKKOL-AFSHARI R., TAVAKOLI A. Growth and stomatal responses of bread wheat genotypes in tolerance to salt stress. Int. J. Biol. Life Sci. 6, 216, 2010.

12. EGEA G., VERHOEF A., VIDALE PL. Towards an improved and more flexible representation of water stress in coupled photosynthesis stomatal conductance models. Agric For Meteorol. 151, 1370, 2011.

13. ZHOU S., DUURSMA RA., MEDLYN BE., KELLY JWG., PRENTICE IC. How should we model plant responses to drought? An analysis of stomatal and non-stomatal responses to water stress. Agric For Meteorol. 182, 204, 2013.

14. CHAVES M.M., FLEXAS J., PINHEIRO C. Photosynthesis under drought and salt stress: regulation mechanisms from whole plant to cell. Ann. Bot. 103, 551, 2009.

15. SIKUKU P.A., NETONDO G.W., Onyango J.C., MUSYIMI D.M. Chlorophyll fluorescence, protein and chlorophyll content of three NERICA rainfed rice varieties under varying irrigation regimes. ARPN J. Agr. Biol. Sci. 5, 19, 2010.

16. TEZARA W., LAWLOR D.W. Effects of water stress on the biochemistry and physiology of photosynthesis in sunflower. Mathis, P, Kluwer Acad. Publs., eds. Dordrecht-Berlin, London, 625, 1995.

17. KANECHI M., KUNITOMO E., INAGAKI N. Water stress effects on ribulose-1,5-bisphosphate carboxylase and its relationship to photosynthesis in sunflower leaves. In: M. Mathis, Kluwer Acad. Publs., Eds- Dordrecht-Berlin, London, 597, 1995.

18. POU A., FLEXAS J., ALSINA M.M., BOTA J., CARAMBULA C., DE HERRALDE F., GALMES J., LOVISOLO C., JIMENEZ M., RIBAS-CARBO M., RUSJAN D., SECCHI F., TOMAS M., ZSOFI Z., MEDRANO H. Adjustments of water use efficiency by stomatal regulation during drought and recovery in the drought-adapted Vitis hybrid Richter-110 $(V$. berlandieri $\times V$. rupestris $)$. Physiologia Plantarum. 134, 313, 2008.

19. CONDON A.G., RICHARDS R.A., REBETZKE G.J. FARQUHAR G.D. Improving water use efficiency and crop yield. Crop Sc. 42, 122, 2002.

20. KHAN HR., PAULL JG., SIDDIQUE KHM., STODDARD FL. Faba bean breeding for drought-affected environments: A physiological and agronomic perspective. Field Crop Res. 115, 279, 2010 .

21. KARDOUS M. Quantification of wind erosion in arid Tunisian: an experimental approach . Doctoral thesis: PARIS University, 12 - VAL-DE-MARNE, 2005.

22. KASSAH A. Oasis and development in dry lands issues, 
challenges and strategies. In Proceedings of the workshop Sirma: Management of natural resources and sustainable development of oasis systems - Nefzaoua, Douz,Tunisia, 6 , 2009.

23. HAKAN S., MEHMET C. Effects of Water Stress on Seed Germination for Select Landscape Plants. Pol. J. Environ. Stud. 24 (2), 689, 2015.

24. SCHITEA M. Results in alfalfa breeding at NARDI Fundulea during 2000-2009. Anale I.N.C.D.A. Fundulea. 73 (2), 63, 2010.

25. CHAVES M.M., MAROCO J.P., PEREIRA J.S. Understanding plant responses to drought- from genes to the whole plant. Funct Plant Biol. 30, 239, 2003.

26. MCKINNEY K. Absorption of light by chlorophyll solutions. J Biol. Chem. 140, 315, 1941.

27. CASTRILLO M., TRUJILLO I. Ribulose-1, 5-bisphosphate carboxilase activity and chlorophyll and protein contents in two cultivars of french bean plants under water stress and rewatering. Photosynthetica. 30, 175, 1994.

28. WANG He., LIU L., ZHOU D. Effects of soil water deficit on seedlings of different Medicago falcata L. populations . Afr J Agr Res. 7 (21), 3228, 2012.

29. YOUSFI N., SLAMA I., GHNAYA T., SAVOURE A., ABDELLY CH. Effects of water deficit stress on growth, water relations and osmolyte accumulation in Medicago truncatula and M. laciniata populations. Comptes Rendus en Biologie. 333, 205, 2010.

30. MISSON L., LIMOUSIN J., RODRIGUEZ R., MATTHEW GL. Leaf physiological responses to extreme droughts in Mediterranean Quercus ilex forest. Plant Cell Env. 33, 1898, 2010.

31. ANTOLÍN M.C., MURO I., SÁNCHEZ-DÍAZ M. Application of sewage sludge improves growth photosynthesis and antioxidant activities of nodulated alfalfa plants under drought conditions. Env. Exp. Bot. 68, 75, 2010.

32. LAWLOR D.W., TEZARA W. Causes of decreased photosynthetic rate and metabolic capacity in water deficient leaf cells- a critical evaluation of mechanisms and integration of processes. Ann Bot. 103, 543, 2009.

33. SÁNCHEZ-DÍAZ M., PARDO M., ANTOLÍN M.C., PEÑA, J., AGUIRREOLEA J. Effect of water stress on photosynthetic activity in the Medicago-Rhizobium-Glomus symbiosis. Plant Sc. 71, 215, 1990.

34. YORDANOV I., VELIKOVA V., TSONEV T. Plant responses to drought, acclimation, and stress tolerance. Photosynthetica. 38, 186, 2000.

35. XING D., WU Y. Photosynthetic response of three climber plant species to osmotic stress induced by polyethylene gly- col (PEG) 6000. Acta Physiologiae Plantarum. 34, 1659, 2012.

36. ERICE G.A., LOUAHLIA S., IRIGOYEN J.J., SANCHEZDIAZ M., THAMI ALAMI I., AVICE J.C. Photosynthesis$\mathrm{N}_{2}$ fixation and taproot reserves during the cutting regrowth cycle of alfalfa under elevated $\mathrm{CO}_{2}$ and temperature. J. Plant. Physiol. 168, 2007, 2011b.

37. WU F., BAO W., LI F., WU N. Effects of drought stress and $\mathrm{N}$ supply on the growth, biomass partitioning and water-use efficiency of Sophora davidii seedlings. Env. Exp Bot. 63, 248, 2008

38. MAFAKHERI A., SIOSEMARDEH A., Bahramnejad B. Effect of drought stress on yield, proline and chlorophyll contents in three chickpea cultivars. Aust. J. Crop Sci. 4, 580, 2010.

39. DIN J., KHAN S.U., ALI I., GURMANI A.R. Physiological and agronomic response of canola varieties to drought stress. J. Anim. Plant Sci. 21,78, 2011.

40. ASTORGA G.I., MELENDEZ L.A. Salinity effects on protein content, lipid peroxidation, pigments and proline in Paulownia imperialis and Paulowina fortune grown in vitro. Electr. J .Biot. 13 (5), 115, 2010.

41. ANJUM S., XIE X., WANG L. Morphological, physiological and biochemical responses of plants to drought stress. J. Afr. Agr. Res. 6 (9), 2026, 2011.

42. COSTA-FRANCA MG., PIMENTAL AT., PEREYRA C., ZUILY-FODIL R.O., LAFFRAY D. Differences in growth and water relations among Phaseolus vulgaris cultivars in response to induced drought stress. Env. Exp Bot. 43, 227, 2000.

43. PINHEIRO C., CHAVESMM., RICARDO CP. Alterations in carbon and nitrogen metabolism induced bywater deficit in the stems and leaves of Lupinus albus L - Journal of Experimental Botany. 52, 1063, 2001.

44. MOHSENZADE S., MALBOOBI MA., RAZAVI K., FARRAH-ASCHTIANI S. Physiological and molecular responses of Aeluropus lagopoides (Poaceae) to water deficit. Env. Exp Bot. 56, 314, 2006.

45. ARANJUELO I., IRIGOYEN J.J., SANCHEZ-DIAZ M. Effect of elevated temperature and water availability on $\mathrm{CO}_{2}$ exchange and nitrogen fixation of nodulated alfalfa plants. Env. Exp. Bot. 59, 99, 2007.

46. ERICE G., LOUAHLIA S., IRIGOYEN JJ., SANCHEZDIAZ M., JEAN-CHRISTOPHE A. Biomass partitioning, morphology and water status of four alfalfa genotypes submitted to progressive drought and subsequent recovery. J. Plant. Physiol. 167, 114, 2010a. 